\title{
Pelayanan Dalam Konteks Masyarakat Perkotaan
}

\author{
Selvester Melanton Tacoy \\ Sekolah Tinggi Filsafat Theologia Jaffray \\ Email: ely_tacoy@yahoo.com
}

\begin{abstract}
Urban community service is a service that must be done by the church. City context services require a contextual service approach, therefore the authors conducted a literature analysis to present an idea of the service of the city context. In serving the city context, the church must begin by equipping the congregation to witness, because the church has a role in a pluralistic society. Because of the complexity of services in the city, we need a counseling center that can help individuals who are vulnerable to mental-psychological disorders. Because poverty is a problem in the city, the church needs to be present by carrying out social actions in an effort to present God's love to others. Educational institutions also play an important role in alleviating poverty in cities, therefore educational institutions need to answer this need. The condition of the city community who keeps trying to interact and build friendships can be facilitated by creating sports groups.
\end{abstract}

Keywords: Ministry, urban, community, church.

\begin{abstract}
Abstrak
Pelayanan masyarkaat perkotaan adalah sebuah pelayanan yang harus dilakukan oleh gereja. Pelayanan konteks kota memerlukan pendekatan pelayanan yang kontekstual, oleh sebab itu penulis melakukan analisis pustaka untuk menyajikan sebuah gagasan pelayanan konkteks kota. Dalam pelayanan konteks kota, gereja harus memulainya dengan memperlengkapi jemaat untuk bersaksi, sebab jemaat memiliki peran dalam masyarakat yang majemuk. Karena kompleksitas pelayanan di kota maka dibutuhkan sebuah pusat konseling yang dapat membantu individu yang rentan terhadap gangguan mental-psikologis. Karena kondisi kemisikinan menjadi masalah di kota maka gereja perlu hadir dengan melakukan aksi sosial sebagai upaya menghadirkan kasih Allah pada sesama. Lembaga pendidikan juga berperan penting dalam mengentaskan kemiskinan di kota, oleh sebab itu perlu lembaga pendidikan yang menjawab kebutuhan ini. Kondisi masyarakat kota yang terus berusaha berinteraksi dan membangun persahabatan dapat difasilitasi dengan membuat grup olah raga.
\end{abstract}

Kata kunci: Pelayanan, perkotaan, masyarakat, gereja.

\section{Pendahuluan}

Pelayanan kota harus dilandasi oleh pengenalan secara utuh terhadap kehidupan masyarakat yang ada di kota tersebut. Pengenalan ini penting karena kehidupan kota sangat kompleks baik dari segi manusianya, keragaman budaya, situasi politik, keadaan ekonomi, bahkan masalah-masalah sosial yang menjadi bagian dari kehidupan kota. Amar berpendapat bahwa: "Suatu kota dapat dikenal bila identitas kota tersebut diketahui dan dipahami baik dan menyeluruh melalui penelusuran ciri-ciri, tanda-tanda atau jati diri, baik elemen fisik (tangible) maupun psikis (intangible), dengan senantiasa memperhatikan kondisi faktual tatanan dan fungsi kehidupan kota, nilai-nilai historis serta nilai-nilai lokal setempat sebagai 
keunikan dan karakteristik tersendiri, tanpa mengabaikan apresiasi masyarakat dan lingkungannya." Ada beberapa ciri yang menonjol tentang masyarakat urban, di antaranya adalah sebagai berikut. Pertama, kehidupan keagamaan masyarakat urban berkurang apabila dibandingkan dengan kehidupan keagamaan di desa. Hal ini disebabkan cara berpikir rasional, didasarkan pada perhitungan eksak yang berhubungan dengan realitas masyarakat. Kehidupan masyarakat urban berada dalam lingkungan ekonomi dan perdagangan. Kedua, orang kota umumnya mengurus diri sendiri tanpa tergantung pada orang lain. ${ }^{2}$

Globalisasi yang terjadi membawa dampak besar bagi perubahan kehidupan masyarakat secara khusus yang ada di daerah perkotaan. Perubahan ini tampak dalam berbagai sendi kehidupan baik itu yang bersifat positif maupun negatif. Pujiwiyana berpendapat bahwa:

Kebudayaan universal muncul, disebarkan melalui semakin banyaknya media global yang kebanyakan dikendalikan oleh, dan bekerja untuk kepentingan modal transnasional. Televisi, dan bentuk-bentuk rekreasi lainnya semakin serupa (dan banyak yang secara menekan) di manapun tempatnya di dunia. Kota yang satu sangat mirip dengan kota-kota lainnya, hotel bentuknya sama di seluruh dunia, dan televisi, iklan dan teknologi komputer tampaknya bekerja tak kenal lelah untuk mewujudkan keseragaman. ${ }^{3}$

Pada era globalisasi seluruh elemen yang terjadi masuk ke dalam proses pembiasaan dan pemberian pengalaman pada individu sehingga banyak mempengaruhi individu maupun kelompok. ${ }^{4}$

Dapat dikatakan bahwa budaya hidup masyarakat kota sangat berbeda dengan masyarakat di desa. Perbedaan budaya hidup ini juga yang menyebabkan perilaku masyarakat tersebut berbeda dalam berbagai hal. Sehubungan dengan kebudayaan, ada beberapa defenisi yang dapat dikemukakan. Soekanto berpendapat bahwa: "Kata kebudayaan berasal dari bahasa sansekerta buddhayah yang merupakan bentuk jamak dari kata 'buddhi' yang berarti budi atau akal. Kebudayaan diartikan sebagai hal-hal yang bersangkutan dengan budi atau akal." E.B Taylor memberikan defenisi mengenai kebudayaan sebagai berikut: "Kebudayaan adalah kompleks yang mencakup pengetahuan, kepercayaan, kesenian, moral, hukum, adat-istiadat dan lain kemampuan-kemampuan serta kebiasaan-kebiasaan yang didapatkan oleh manusia sebagai anggota masyarakat."

Soemardjan dan Soemardi berpendapat bahwa kebudayaan adalah semua hasil karya, rasa dan cipta masyarakat. Karya masyarakat menghasilkan teknologi dan kebudayaan kebendaan atau kebudayaan jasmaniah (material culture) yang diperlukan oleh manusia untuk menguasai alam sekitarnya. Tujuannya adalah agar kekuatan serta hasilnya dapat diabdikan untuk keperluan masyarakat. Kemudian rasa yang meliputi jiwa manusia, yang mewujudkan

\footnotetext{
${ }^{1}$ Amar, "Identitas Kota, Fenomena Dan Permasalahannya," Ruang 1, no. 1 (2009): 55.

2 Purwantini, "Urbanisme, Urbanisasi, Dan Masyarakat Urban Di Jakarta Dalam Novel Senja Di Jakarta,” Atavisme 19, no. 2 (2016): 163.

3 Pujiwiyana, "Perubahan Perilaku Masyarakat Ditinjau Dari Sudut Budaya," Tradisi 1, no. 1 (2010): 23.

${ }^{4}$ Sukma Erni Nurhayati and Suriani, "Sustainable Life Style Masyarakat Perkotaan (Studi Tentang Gaya Hidup Berkelanjutan Masyarakat Perkotaan Di Riau),” Sorot 11, no. 2 (2008): 76.

${ }^{5}$ Soerjono Soekanto, Sosiologi Suatu Pengantar (Jakarta: PT Raja Grafindo Persada, 2002), 172-173.
} 
segala kaidah-kaidah dan nilai-nilai sosial yang diperlukan guna mengatur masalah-masalah kemasyarakatan termasuk agama, ideologi, kebatinan, kesenian dan semua unsur yang merupakan hasil ekspresi jiwa manusia yang hidup sebagai anggota masyarakat. Selanjutnya cipta merupakan kemampuan mental, kemampuan berpikir orang-orang yang hidup bermasyarakat dan yang antara lain menghasilkan filsafat serta ilmu pengetahuan. ${ }^{6} \mathrm{Kraft}$, seorang antropolog Kristen, mendefinisikan budaya sebagai sistem yang mencakup seluruh cara hidup dan cara berpikir sekelompok masyarakat sehingga mereka dipersatukan dan memberi kelompok tersebut "rasa" jati diri dan harga diri. Selanjutnya ia mengatakan bahwa budaya menunjukkan cara bagaimana sekelompok masyarakat bertindak bersama agar tetap bertahan dan dapat mengungkapkan rasa dan keyakinan-keyakinan mereka serta mewujudkan kesenangan hidupnya. ${ }^{7}$ Dengan demikian dapat dipahami bahwa budaya berhubungan dengan totalitas kehidupan manusia dalam cara pandang, cara berperilaku, cara berinteraksi dengan sesama dan lingkungannya, cara mengaktualisasikan diri, serta berbagai karya yang dihasilkan.

Dengan memperhatikan berbagai hal yang ada dalam kehidupan warga kota termasuk di dalamnya kompleksitas permasalahan serta ragam budaya yang dimiliki oleh masyarakatnya maka gereja diharapkan dapat melakukan pelayanan secara kontekstual untuk menjawab kebutuhan individu-individu di perkotaan. Keadaan perkotaan memiliki tantangan tersendiri bagi gereja namun gereja harus dapat menjalankan fungsinya sebagai garam dan terang untuk menghadirkan Kristus di tengah-tengah masyarakat kota.

\section{Metode}

Karena penulis ingin menyusun sebuah usulan pendekatan pelayanan konteks kota maka penulis menggunakan pendekatan penelitian pustaka. Beberapa sumber literatur penulis gunakan dalam penulisan ini. Hasil dari sumber pustaka kemudian penulis sajikan secara deskriptif tematis. Penulis terlebih dahulu menyajikan gambaran kehidupan masyarakat kota lalu dilanjutkan dengan menyajikan gagasan konsep pendekatan pelayanan konteks kota.

\section{Hasil dan Pembahasan}

\section{Gambaran Kehidupan Masyarakat Kota}

Masyarakat perkotaan sering disebut juga urban community. Pengertian ini lebih ditekankan pada sifat-sifat kehidupan serta ciri-ciri kehidupannya yang berbeda dengan masyarakat pedesaan. Perhatian khusus masyarakat kota tidak terbatas pada aspek-aspek, seperti pakaian, makanan, dan perumahan, tetapi lebih luas lagi. ${ }^{8}$ Masyarakat kota bersifat heterogen dan multikultural serta memiliki dinamika kehidupan yang tinggi. Di sisi lain

\footnotetext{
${ }^{6}$ Soekanto, Sosiologi Suatu Pengantar; Selo Soemardjan and Soelaeman Soemardi, Setangkai Bunga Sosiologí (Jakarta: Jajasan Badan Penerbit Fakultas Ekonomi Universitas Indonesia, 1964).

${ }^{7}$ Gideon I Tanbunaan, Sebuah Bunga Rampai Pertumbuhan Gereja (Yogyakarta: Yayasan Andi, 1994), 149-150; Charles H. Kraft, Christianity In Culture: A Study In Biblical Theologizing In Cross-Cultural Perspective, 25th Annv edition. (Maryknoll, N.Y: Orbis Books, 2005).

${ }^{8}$ Adon Nasrullah Jamaludin, Sosiologi Perkotaan (Bandung: Pustaka Setia, 2017), 33.
} 
perkembangan dan perubahan di kota begitu cepat sehingga mempengaruhi pola pikir dan gaya hidup masyarakat kota. Adapun karakteristik masyarakat kota yang dapat menjadi masukan bagi gereja untuk mengembangkan pelayanan secara menyeluruh adalah:

\section{Individualisme}

Perilaku individualis pada masyarakat kota secara umum bisa dibedakan dalam dua aspek, yaitu: perwujudan dalam ungkapan fisik (spasial, material dan bentuk), serta perwujudan dalam sikap dan periIakunya. Kedua aspek tersebut bersama-sama mengupayakan suatu "pertahanan" atau "perlawanan" terhadap kondisi kehidupan kota. ${ }^{9}$ Masyarakat kota memiliki kehidupan yang berbeda dengan masyarakat di desa. Sikap hidup individualisme sangat melekat dalam kehidupan mereka sehari-hari. Masyarakat kota cenderung mementingkan diri sendiri sehingga dalam pergaulan sehari-hari, mereka terkesan tertutup dengan lingkungan sekitarnya. Kemandirian dalam bersikap juga nyata dalam kehidupan mereka sehari-hari yang dibuktikan dengan adanya sikap menjauhkan diri dari pergaulan dengan sesama di lingkungan sekitarnya sehingga tidak jarang tetangga yang berada disekelilingnya pun tidak dikenal dengan baik. Sehubungan dengan sikap individualisme masyarakat kota maka Chandra mengungkapkan bahwa: "Anomistis adalah hal lain yang menjadi ciri kejiwaan orang kota. Dengan istilah ini dimaksudkan bahwa orang kota cenderung untuk tidak lagi memperhatikan dengan saksama manusia-manusia lain yang sering ia jumpai. Dengan demikian terpisahlah lingkup hidup pribadi dan lingkup hidup sosial atau fungsional. Semakin besar kotanya, semakin besar tingkat tingkat anonimitas yang ada di tengah masyarakat kota ini. Anonimitas yang berlebihan membuat hubungan yang tidak bersifat pribadi atau yang bersifat fungsional tadi merasuk ke tengah hidup keluarga." ${ }^{10}$ Kesibukan setiap warga kota dalaln tempo yang cukup tinggi dapat mengurangi perhatian terhadap sesamanya. Apabila hal ini berlebihan akan menimbulkan sifat acuh tak acuh atau kurang metupunyai toleransi sosial. ${ }^{11}$

Sikap Individualisme yang dihidupi oleh masyarakat kota ini menyebabkan pergaulan dengan sesama menjadi renggang yang berdampak pada tidak adanya ikatan sosial yang kuat di antara lingkungan tersebut. Sikap individualisme ini menunjuk pada keadaan hidup orangorang kota yang cenderung lebih mengandalkan diri serta mengutamakan diri sendiri tanpa mau bergantung kepada orang lain. Sikap mementingkan diri sendiri ini tidak jarang menciptakan konflik-konflik dalam berbagai dimensi kehidupan sehingga menciptakan ketidakstabilan dan ketidakharmonisan hidup. Sikap individualisme juga membuat hubungan dalam rumah tangga menjadi renggang sehingga tidak adanya keharmonisan diantara anggota-anggotanya karena mereka sibuk dengan kegiatannya masing-masing. Sikap individualisme juga tampak dalam kehidupan masyarakat kota yang memproteksi diri secara berlebihan yang terlihat dengan adanya bangunan-bangunan rumah yang dipagari dengan

9 Sumardjito, "Permasalahan Perkotaan Dan Kecenderungan Perilaku Individualis Penduduknya," Cakrawala Pendidikan XVIII, no. 3 (1999): 134.

${ }^{10}$ Robby I. Chandra, Budaya Kota Kawula Muda Dan Media Modern (Jakarta: Binawarga, 1998), 84.

11 "Permasalahan Perkotaan Dan Kecenderungan Perilaku Individualis Penduduknya," 133. 
pagar yang berlapis-lapis sehingga menjadi pemisah dengan sesamanya sebagai pertanda hubungan sosial yang sangat rapuh dengan lingkungannya. Kehidupan yang berpusat pada diri cenderung membuat masyarakat kota tidak bergairah terhadap hal-hal yang sifatnya keagamaan sehingga akhirnya kehidupan rohani mereka dangkal. Lebih ironis lagi bahwa pemusatan kehidupan terhadap diri ini cenderung membuat diri sebagai 'tuhan' atau dengan kata lain "mentuhankan diri." Di sisi lain sikap mementingkan diri ini juga menyebabkan masyarakat kota cenderung mempergunakan berbagai cara untuk memenuhi keinginannya tanpa memperdulikan kebutuhan orang lain bahkan mungkin juga dapat mengorbankan hak atau kepentingan orang lain.

\section{Materialisme}

Meterialisme adalah suatu sifat yang menganggap penting adanya kepemilikan barang-barang, yang mana kepemilikan atas barang tersebut dirasa akan menunjukkan statusnya seperti pembelian diluar kebutuhan, membuat orang lain terkesan, meningkatkan identitas diri dan meningkatkan kepuasan. ${ }^{12}$ Materialisme ialah suatu pemikiran yang berasumsi bahwa perasaan senang dan pengakuan dalam menunjukkan status dapat diatasi dengan kepemilikan suatu barang. Seseorang dengan sifat materialistis berasumsi jika harta tidaklah cuma barang, tapi juga kedudukan dalam memperlihatkan harta dan tahtanya. ${ }^{13}$ Bagi masyarakat kota semboyan bahwa uang adalah segala-galanya bukanlah semboyan semata tetapi hal ini merupakan sebuah kenyataan yang menunjuk pada sikap hidup masyarakat kota yang cenderung materialistis. Di kota perputaran uang sangat besar karena kota merupakan pusat perekonomian dan perdagangan. Di kota, kebutuhan hidup sangat tinggi, karena itu setiap individu berupaya untuk memenuhi kebutuhannya yang sangat beragam itu. Hal tersebut menyebabkan orientasi hidup terfokus semata-mata pada hal-hal yang sifatnya materi. ${ }^{14}$

Individu yang memiliki orientasi materialisme akan memusatkan perhatiannya pada materi dan harta benda, termasuk di dalamnya uang sebagai sesuatu hal yang utama dalam hidupnya. Individu tersebut percaya bahwa materi dan harta benda dapat memberinya kebahagiaan, kesejahteraan, dan juga kepuasan. ${ }^{15}$ Sikap materialistis dalam kehidupan masyarakat kota di satu sisi menjelaskan tentang tekanan kebutuhan hidup yang harus dipenuhi tetapi di sisi lain juga menunjuk pada sifat manusia yang tidak pernah puas dengan apa yang dimiliki sehingga terus berusaha memuaskan keinginannya dengan mengumpulkan segala sesuatu yang sifatnya materi. Sikap materialistis juga disebabkan karena masyarakat kota memandang hal-hal materi sebagai salah satu faktor penentu status sosial. Materialism ialah suatu

${ }^{12}$ I Putu Risky Adityawan and A. A Gede Agung Artha Kusuma, "Peran Materialisme Memoderasi Persepti Nilai Dan Consumer Innovativeness Terhadap Keputusan Pembelian (Studi Pada Produk Iphone Di Kota Denpasar)," E-Jurnal Manajemen 7, no. 3 (2018): 15-16.

13 Adityawan and Kusuma, "Peran Materialisme Memoderasi Persepti Nilai Dan Consumer Innovativeness Terhadap Keputusan Pembelian (Studi Pada Produk Iphone Di Kota Denpasar).”

${ }^{14}$ Selvester M. Tacoy, Membimbing Dengan Hati, (Jakarta: Media Gracia, 2011), 73.

15 Adityawan and Kusuma, "Peran Materialisme Memoderasi Persepti Nilai Dan Consumer Innovativeness Terhadap Keputusan Pembelian (Studi Pada Produk Iphone Di Kota Denpasar).” 
pemikiran yang berasumsi bahwa perasaan senang dan pengakuan dalam menunjukkan status dapat diatasi dengan kepemilikan suatu barang. Seseorang dengan sifat materialistis berasumsi jika harta tidaklah cuma barang, tapi juga kedudukan dalam memperlihatkan harta dan tahtanya. ${ }^{16}$ Hal ini sesuai dengan kenyataan yang ada bahwa, orang-orang di kota yang memiliki kekayaan banyak biasanya menerima penghargaan dari lingkungannya secara layak dan mereka dianggap sebagai orang terpandang yang harus dihargai. Dengan uang/kekayaan yang dimiliki, orang-orang di kota memperoleh beragam kemudahan dari berbagai pihak sehingga mereka dapat melakukan apa saja dan mencapai segala hal yang mereka inginkan. Berbagai kenyataan ini yang membuat orang-orang di kota cenderung lebih berorientasi kepada hal-hal yang sifatnya materi dan menempatkan hal-hal keagamaan/rohani pada posisi yang rendah. ${ }^{17}$ Sikap materialistis ini juga berhubungan dengan pilihan gaya hidup setiap individu untuk menyesuaikan diri dengan lingkungannya sekaligus menjadi sebuah identitas diri. Aspek utama dari materialisme adalah penggunaan kepemilikan dan barang-barang konsumen untuk mengkomunikasikan identitas personal seorang individu.

Cara khusus yang dipilih seseorang untuk mengekspresikan diri, tak disangsikan adalah bagian dari usaha dirinya untuk mencari gaya hidup pribadinya. Dengan cara yang nyaris sama kita biasanya mengindividualisasikan gaya hidup kita, namun selalu ada kemiripan yang jelas dengan salah satu model gaya hidup yang telah dipaketkan dan dipasarkan oleh suatu subkultur. Dalam menjajakan model gaya hidup dan memikat perhatian kita, subkultur biasanya menyerang milik psikologis kita yang paling rawan: citra diri (self image) kita. Kita diombang-ambing oleh banyak janji psikologis mereka. Mereka menggelitik khayalan kita yang paling pribadi, mungkin dengan cara yang jauh lebih canggih dan halus dibandingkan dengan indoktrinasi rezim politik yang paling otoriter sekalipun. ${ }^{18}$ Sikap materialistis dalam hubungannya dengan gaya hidup ini menyebabkan masya-rakat kota menjadi pekerja keras. Mereka bekerja siang malam tanpa mengenal lelah untuk memenuhi berbagai kebutuhan mereka tersebut. Fenomena yang menarik dari masyarakat kota yang bekerja ialah bahwa mereka cenderung untuk tidak menetap pada suatu tempat pekerjaan tetapi berpindahpindah dari satu pekerjaan kepada pekerjaan lain demi pencapaian hal-hal yang sifatnya materi bagi kemajuan hidup. Mereka juga memiliki pikiran yang kreatif dalam menciptakan peluang kerja atau usaha bagi keberhasilan hidup. Para pebisnis pun tidak mengembangkan usahanya pada satu bidang saja tetapi cenderung untuk mengembangkan usahanya tersebut pada berbagai bidang. ${ }^{19}$

\section{Konsumerisme}

Tacoy mengungkapkan bahwa Hoed (2014) menjelaskan konsumerisme adalah budaya "membeli untuk membeli" dengan tujuan untuk menjadi "berbeda" (eksklusif),

\footnotetext{
${ }^{16}$ Ibid.

${ }^{17}$ Selvester M. Tacoy, Membimbing Dengan Hati, (Jakarta: Media Gracia, 2011), 73-74.

${ }^{18}$ David Chaney, Life Style: Sebuah Pengantar Konprehensif (Bandung: Jalasutra, 2004), 14.

${ }^{19}$ Selvester M. Tacoy, Membimbing Dengan Hati, (Jakarta: Media Gracia, 2011), 74.
} 
khususnya sebagai simbol menjadi bagian dari "kebudayaan internasional" (tinggi). Ya, konsumerisme adalah upaya membeli status dengan membeli materi yang menyimbolkan suatu status. ${ }^{20}$ Di kota tersedia berbagai benda, maupun jasa yang dapat memenuhi kebutuhan warganya. Maraknya pembangunan pusat-pusat perbelanjaan di satu sisi sangat membantu dalam menyerap tenaga kerja, namun di sisi lain menandakan bahwa masyarakat kota sedang dibawa masuk pada kondisi untuk menikmati segala yang ditawarkan. ${ }^{21}$ Masyarakat kota juga dapat terperangkap dalam pola hidup konsumerisme karena adanya beragam iklan produk yang dimuat dalam berbagai media cetak maupun yang ditayangkan di media elektronik. Masyarakat modern berlomba-lomba untuk mencari produk-produk yang baru. Rasa ingin tahu yang sangat besar serta ketidakmauan untuk ketinggalan jaman menyebabkan mereka meninggalkan produk yang lama serta beralih ke produk yang baru. ${ }^{22}$ Kemajuan internet, perkembangan teknologi informasi, kebangkitan media sosial serta hadirnya berbagai startup yang memberikan berbagai kemudahan juga semakin memberi pengaruh pada pola hidup konsumerisme masyarakat kota.

Konsumerisme juga menjelaskan tentang pemenuhan selera dari setiap masyarakat kota sebagai konsumen. Penekanannya ialah pada pemenuhan selera dan tidak sebatas pada kebutuhan. Konsumsi tidak harus dipahami sebagai konsumsi nilai-manfaat, suatu keperluan material, tetapi terutama sebagai konsumsi tanda. ${ }^{23}$ Jameson menuliskan bahwa budaya adalah unsur yang paling penting dalam masyarakat konsumen itu sendiri; tidak ada masyarakat yang jenuh oleh tanda dan imaje seperti masyarakat ini. Benda-benda konsumen yang bersifat keduniaan dan dibutuhkan sehari-hari kemudian diasosiasikan dengan kemewahan, eksotika, keindahan dan romansa dengan "kegunaan" asli dan fungsionalnya yang semakin sulit untuk diuraikan. Baudrillard (1983) telah memberikan perhatian pada peran penting media massa elektronik pada masyarakat kapitalis baru. Televisi menghasilkan suatu kejenuhan image dan informasi yang mengancam rasa kita terhadap realitas. Kemenangan budaya yang memberikan dorongan terhadap dunia simulasional yang di dalamnya perkembangbiakkan tanda dan imaje telah menghapuskan perbedaan antara yang nyata dengan yang imajiner. Hal ini mempunyai arti bahwa "kita hidup di mana saja selalu ada halusinasi realitas yang bersifat estetis." Budaya konsumen secara efektif adalah budaya postmodern, suatu budaya kedangkalan yang di dalam budaya itu nilai-nilai ditransevaluasi (dievaluasikan oleh prinsipprinsip baru) dan seni telah mengungguli realitas. ${ }^{24}$

Masyarakat kota cenderung terbius dengan berbagai tawaran yang diberikan karena nilai yang terkandung dibalik produk-produk tersebut. Disamping itu ada juga kepuasan

20 Saefu Zaman, "Pola Konsumtif Masyarakat Urban Dalam Perspektif Semiotik Dan Budaya," Paradigma 7, no. 1 (2017): 43-44.

${ }^{21}$ Selvester M. Tacoy, Membimbing Dengan Hati, (Jakarta: Media Gracia, 2011), 75-76.

${ }^{22}$ Selvester M Tacoy, Identitas Gereja: Sarang Penyembahan vs Sarang Penyamun (Jakarta: Calvary Media, 2005), 73.

${ }^{23}$ Mike Featherstone, Postmodernisme Dan Budaya Konsumen (Yogyakarta: Pustaka Belajar, 2005), 202.

\footnotetext{
${ }^{24}$ Ibid., 203-204.
} 
secara psikologis yang dirasakan oleh masyarakat kota apabila mereka dapat menikmati sebuah produk yang ada sekalipun hal tersebut tidak berhubungan dengan kebutuhan hidup yang mereka perlukan. Di sisi lain pemuasan selera yang dilakukan oleh penduduk kota merupakan sebuah rasa kebanggaan yang dapat diberikan oleh seorang individu kepada individu lainnya bahwa ia mampu dan layak menikmatinya. Hal ini juga berhubungan dengan peneguhan terhadap sebuah status sosial yang dimiliki oleh seseorang. Di kota, konsumerisme juga ditandai dengan adanya persaingan merek produk yang dilakukan oleh para pebisnis yang bergerak dalam berbagai dunia usaha yang kesemuanya itu dimaksudkan untuk menciptakan pelanggan-pelanggan dalam tingkatan kelasnya masing-masing. ${ }^{25}$

Dengan demikian dapat disimpulkan bahwa penekanan pada budaya konsumerisme masyarakat kota tidak hanya sekedar pada pemenuhan kebutuhan hidup tetapi juga berkaitan dengan pemenuhan selera masyarakat kota yang didalamnya terkandung beragam nilai dari produk-produk yang digunakan seperti nilai eksotika, kemewahan, prestise, status sosial, serta berbagai kandungan nilai lainnya yang memberikan kepuasan bagi penggunanya sekalipun harus memperolehnya dengan harga yang mahal.

\section{Hedonisme}

Hedonisme diambil dari bahasa Yunani hedonismos dari akar kata hedone, artinya kesenangan. Paham ini berusaha menjelaskan adalah baik apa yang memuaskan keinginan manusia dan apa yang meningkatkan kuantitas kesenangan itu sendiri. ${ }^{26}$ Hedonisme merupakan ajaran atau pandangan bahwa kesenangan atau kenikmatan merupakan tujuan hidup dan tindakan manusia. ${ }^{27}$ Perkembangan kehidupan perkotaan secara tidak langsung membentuk gaya hidup hedonis, sikap pragmatis dan budaya konsumtif dalam kehidupan modern. Kondisi tersebut membawa dampak yang tidak kecil pada tumbuhnya global culture yang berujung pada hegemoni, kekacauan dan trans-nasional budaya, sehingga terjadi reaksi identitas pada kehidupan modern. ${ }^{28}$ Gaya hidup hedonis adalah suatu pola hidup yang aktivitasnya untuk mencari kesenangan hidup, seperti lebih banyak menghabiskan waktu di luar rumah, lebih banyak bermain, senang pada keramaian kota, senang membeli barang mahal yang disenanginya, serta selalu ingin menjadi pusat perhatian. ${ }^{29}$

Di kota banyak fasilitas umum seperti tempat-tempat hiburan malam, diskotik, bioskop-bioskop, kafe-kafe, dan tempat-tempat hiburan lainnya yang dibuka untuk menjawab kebutuhan masyarakat akan hiburan dan kenyataannya tempat-tempat tersebut ramai

${ }^{25}$ Selvester M. Tacoy, Membimbing Dengan Hati, (Jakarta: Media Gracia, 2011), 76-77.

${ }^{26}$ Sigit Wibawanto, "Gaya Hidup Hedonisme Terhadap Perilaku Pembelian Di Pasar Modern," Fokus Bisnis 15, no. 01 (2016): 62.

${ }^{27}$ Wibawanto, "Gaya Hidup Hedonisme Terhadap Perilaku Pembelian Di Pasar Modern."

28 Rofhani, "Ekspresi Dan Representasi Budaya Perempuan Muslim Kelas Menengah Di Surabaya," Islamica 11, no. 2 (2017): 277-278.

${ }^{29}$ Muslim Sabarisman, "Gaya Hidup Hedonisme Dan Fenomena Trafficking Anak: Studi Kasus Di Kota Surabaya,” Sosiokonsepsia 16, no. 02 (2011): 190. 
dikunjungi oleh warga kota. ${ }^{30}$ Pola hidup take and give sangat kental melekat dalam kehidupan masyarakat modern sehingga untuk sesuatu yang memberikan kepuasan, keuntungan, kebaikan atau peningkatan hidup, mereka tidak tanggung-tanggung untuk mengorbankan apa saja yang dimiliki baik waktu, tenaga maupun uang/materi. Salah satu contoh ialah bahwa dunia hiburan sangat diminati oleh masyarakat modern karena merupakan faktor penting yang memberikan kepuasan sekalipun harus mengeluarkan biaya yang sangat besar. ${ }^{31}$ Fokus kepada kesenangan diri membuat masyarakat kota berupaya untuk melayani segala keinginan mereka sekalipun hal tersebut bertentangan dengan etika dan moralitas. Model berpikir dari kaum hedonistis ini ialah apa yang telah dihasilkan dalam pekerjaan sepantasnyalah harus dinikmati untuk menyenangkan diri. Hal ini menyebabkan terjadinya penyimpangan-penyimpangan moral seperti adanya PIL (pria idaman lain) atau WIL (wanita idaman lain) dalam sebuah hubungan pernikahan. Di kalangan kaum muda terjadilah hubungan seks bebas, dan hal-hal lainnya yang menunjuk pada runtuhnya nilai-nilai agama/rohani dalam kehidupan masyarakat kota. Budaya hedonisme ini dengan jelas tampak dalam slogan-slogan yang sering dikumandangkan oleh kaum muda atau yang biasanya tertulis di baju-baju kaos yang digunakan oleh kaum muda bahwa "muda kaya raya, tua foyafoya, mati masuk surga." 32 Singkatnya, hedonisme telah menjadi bagian yang tidak terpisahkan dari kehidupan masyarakat kota sehingga mempengaruhi cara berpikir dan cara berperilaku setiap individu baik dalam hubungan dengan diri sendiri maupun terhadap sesamanya. Hedonisme juga sepertinya telah menjadi norma baru bagi masyarakat kota sehingga seringkali malampaui etika dan moralitas yang dijunjung tinggi bersama bahkan menabrak aturan-aturan yang ada dengan alasan untuk mencapai sebuah kesenangan diri.

\section{Masalah-Masalah Dalam Masyarakat Kota}

Kenyataan bahwa kota memiliki daya tarik sehingga menyebabkan banyak orang datang ke kota merupakan sebuah realita yang tidak dapat dipungkiri. Namun di kota juga terdapat berbagai masalah yang sangat kompleks karena kehidupan masyarakat kota yang sangat majemuk secara suku, agama, budaya, profesi, tingkatan sosial atau status sosial serta keanekaragaman lainnya.

Durkheim berharap bahwa kehidupan urban bisa menjadi ruang bagi kreativitas, kemajuan, dan sebuah tatanan moral yang baru, tapi juga khawatir bahwa ia bisa menjadi arena kemerosotan moral dan anomie. Marx, di satu sisi, melihat kota sebagai tanda kemajuan dan lompatan besar dalam produktivitas yang dibawa oleh kapitalisme, dan, di sisi lain, sebagai tempat kemiskinan, ketidakpedulian dan kekotoran. ${ }^{33}$

\footnotetext{
${ }^{30}$ Selvester M. Tacoy, Membimbing Dengan Hati, (Jakarta: Media Gracia, 2011), 77.

${ }^{31}$ Selvester M. Tacoy, Identitas Gereja: Sarang Penyembahan vs Sarang Penyamun, (Jakarta: Calvary Media, 2005), 73.

${ }^{32}$ Selvester M. Tacoy, Membimbing Dengan Hati, (Jakarta: Media Gracia, 2011), 78.

${ }^{33}$ Chris Barker, Cultural Studies: Teori Dan Praktik (Yogyakarta: Bentang, 2005), 389-390.
} 
Kompleksitas kehidupan kota inilah yang menyebabkan terjadinya konflik-konflik, kesenjangan hidup maupun masalah-masalah sosial lainnya yang mempengaruhi kehidupan masyarakat di kota tersebut.

\section{Kemiskinan}

Dalam laporan yang dikeluarkan dari World Bank (200) diketahui ada lima faktor yang dianggap dapat mempengaruhi terjadinya kemiskinan, yaitu: pendidikan, jenis pekerjaan, gender, akses terhadap pelayanan kesehatan dasar dan infrastruktur dan lokasi geografis. $^{34}$ Kemiskinan dipandang sebagai ketidakmampuan dari sisi ekonomi untuk memenuhi kebutuhan dasar makanan dan bukan makanan yang diukur dari sisi pengeluaran (BPS). ${ }^{35}$ Kemiskinan merupakan sebuah kenyataan yang tidak dapat disangkal dalam kehidupan masyarakat kota. Kondisi rakyat kota yang miskin juga ditandai dengan munculnya berbagai organisasi di kota yang memperjuangkan hak warga miskin kota. Organisasiorganisasi ini melakukan berbagai demonstrasi untuk meminta pemerintah memperhatikan secara serius warga kota yang miskin. Dampak dari kemiskinan dapat dilihat dari maraknya pengemis yang meminta-minta baik di persimpangan jalan maupun yang berjalan dari rumah ke rumah. Kemiskinan juga membuat anak-anak mengalami putus sekolah dan bekerja membantu orang tua mereka dengan menjadi penyemir sepatu, penjual koran, pengamen, pengemis, atau pemulung.

\section{Prostitusi}

Masalah prostitusi merupakan masalah sosial karena perbuatan tersebut menyimpang dari norma-norma dan nilai-nilai masyarakat. ${ }^{36}$ Salah satu masalah yang ada dalam kehidupan kota ialah prostitusi (pelacuran). Praktek prostitusi yang ada dalam masyarakat kota terjadi baik secara tersembunyi maupun terang-terangan. Hal ini dapat dilihat dengan adanya berbagai tempat yang digunakan mulai dari hotel-hotel berbintang sampai pada tempat tinggal biasa. Kartono mengemukakan defenisi prostitusi sebagai berikut: Prostitusi adalah bentuk penyimpangan seksual, dengan pola-pola organisasi impuls/dorongan seks yang tidak wajar dan tidak terintegrasi, dalam bentuk pelampiasan nafsu-nafsu seks tanpa kendali dengan banyak orang (promiskuitas), disertai eksploitasi dan komersialisasi seks, yang impersonal tanpa afeksi sifatnya. Pelacuran merupakan peristiwa penjualan diri (persundalan) dengan jalan memperjualbelikan badan, kehormatan dan kepribadian kepada banyak orang untuk memuaskan nafsu-nafsu seks, dengan imbalan pembayaran. ${ }^{37}$

\footnotetext{
34 Nunung Nurwati, "Kemiskinan: Model Pengukuran, Permasalahan Dan Alternatif Kebijakan," Jurnal Kependudukan Padjadjaran 10, no. 1 (2008): 5.

${ }^{35}$ Noor Zuhdiyaty and David Kaluge, "Analisis Faktor-Faktor Yang Mempengaruhi Kemiskinan Di Indonesia Selama Lima Tahun Terakhir (Studi Kasus Pada 33 Provinsi),” Jibeka 11, no. 2 (2017): 27.

${ }^{36}$ Krista Surbakti, "Prostitusi Di Bukit Lawang (Kajian Mengenai Faktor Penyebab Dan Respon Masyarakat Dalam Perspektif Dunia Pendidikan),” Stindo Profesional 20, no. 2 (2017): 42.

${ }^{37}$ Kartono Kartini, Patologi Sosial (Jakarta: PT Raja Grafindo Persada, 2001), 185.
} 
Prostitusi (pelacuran) merupakan penyakit dalam masyarakat yang harus dipahami secara utuh dengan memperhatikan berbagai faktor yang menjadi pemicunya. Masalah prostitusi dipicu oleh kehidupan kota yang penuh dengan berbagai tantangan dan persaingan. Di kota biaya hidup sehari-hari sangat tinggi karena itu tidak jarang orang-orang yang tidak dapat bertahan terhadap situasi ini lebih memilih jalan pintas untuk dapat memenuhi kebutuhan hidupnya dengan melacurkan dirinya. Masalah ekonomi inilah yang pada umumnya merupakan pemicu timbulnya pelacuran. Masalah prostitusi juga timbul seiring dengan meningkatnya pergerakan masyarakat desa ke kota (urbanisasi) yang berdampak pada masalah kemiskinan karena kurangnya pendidikan dan keahlian sehingga tidak mampu bersaing dalam dunia kerja. Orang-orang yang datang dari desa ini akhirnya dipekerjakan sebagai pekerja-pekerja seks di berbagai tempat hiburan maupun di tempat-tempat lainnya.

Pelacuran merupakan salah satu fenomena sosial dalam masyarakat yang sangat kompleks, baik dari segi sebab-sebabnya, prosesnya maupun implikasi soasial yang ditimbulkannya. Pelacuran dengan berbagai versinya merupakan bisnis yang abadi sepanjang zaman. Karena disamping disebut sebagai profesi yang tertua, jasa pelacuran pada hakekatnya tetap dicari oleh anggota masyarakat yang tidak terpenuhi kebutuhan seksualnya. ${ }^{38}$ Di sisi lain pelacuran yang berkembang pesat di kota menjelaskan tentang keadaan kota yang penuh dengan hiburan (entertain) yang bagi kaum profesional dipandang sebagai sebuah paket pelayanan yang diberikan kepada rekan bisnis.

\section{Narkoba Dan Seks Bebas}

Anak-anak remaja dan pemuda di kota rentan terhadap berbagai masalah sosial yang sangat kompleks. Hal ini beranjak dari kenyataan bahwa usia seperti ini merupakan saat di mana remaja-pemuda sedang mencari jati dirinya. Erikson menjelaskan bahwa: "Identitas diri yang dicari remaja, berupa usaha untuk menjelaskan siapa dirinya, apa peranannya dalam masyarakat. Apakah ia seorang anak atau seorang dewasa? Apakah nantinya ia dapat menjadi seorang suami atau ayah? Apakah ia mampu percaya diri sekalipun latar belakang ras atau agama atau nasionalnya membuat beberapa orang merendahkannya? Secara keseluruhan, apakah ia akan berhasil atau gagal?. ${ }^{39}$ Seringkali demi sebuah jati diri, remaja-pemuda melakukan berbagai hal yang sangat merugikan diri sendiri dan orang lain. Masalah tawuran yang terjadi diantara remaja-pemuda sering bersumber dari sebuah upaya untuk mempertahankan identitas diri baik secara pribadi maupun kelompok.

Di sisi lain remaja-pemuda juga mudah untuk terjerat dalam masalah narkoba, seks bebas, dan hal-hal lainnya karena pengaruh dari teman-teman sepergaulannya. Pergaulan bebas ini tidak jarang menjerumuskan remaja-pemuda ke dalam berbagai masalah yang rumit dan menghancurkan masa depannya. Sehubungan dengan pengaruh teman-teman sepergaulan

\footnotetext{
38 St. Fatimah Tola Rasyid and Ruliati, "Praktek Prostitusi Terhadap Penyalahgunaan Izin SPA," Equilibrium IV, no. 1 (2016): 109.

${ }^{39}$ Elisabeth B Hurlock, Psikologi Perkembangan: Suatu Pendekatan Sepanjang Rentang Kehidupan (Jakarta: Erlangga, 1980), 208.
} 
ini maka Hurlock menjelaskan bahwa: "Karena remaja lebih banyak berada di luar rumah bersama dengan teman-teman sebaya sebagai kelompok, maka dapatlah dimengerti bahwa pengaruh teman-teman sebaya pada sikap, pembicaraan, minat, penampilan, dan perilaku lebih besar daripada pengaruh keluarga. Misalnya sebagian besar remaja mengetahui bahwa bila mereka memakai model pakaian yang sama dengan pakaian anggota kelompok yang popular, maka kesempatan baginya untuk diterima oleh kelompok menjadi lebih besar. Demikian pula bila anggota kelompok mencoba minum alkohol, obat-obat terlarang atau rokok, maka remaja cenderung mengikutinya tanpa memperdulikan perasaan mereka sendiri akibatnya." ${ }^{40}$ Secara psikologis remaja-pemuda mudah dipengaruhi sehingga mereka menjadi target pasar dari para pengedar obat-obat terlarang. Masalah narkoba dan seks bebas juga akhirnya menimbulkan berbagai masalah yang lain seperti timbulnya penyakit AIDS, kehamilan di luar nikah dan juga maraknya aborsi.

Kejahatan-Kejahatan

Kartono mengemukakan defenisi kejahatan sebagai berikut: "Secara yuridis formal, kejahatan adalah bentuk tingkah laku yang bertentangan dengan moral kemanusiaan (immoral), merugikan masyarakat, a-sosial sifatnya dan melanggar hukum serta undangundang pidana." ${ }^{\text {41 }}$ Korelasi antara kejahatan dan pengangguran secara positif sudah lama dibuktikan. Misalnya, ketika pengangguran meningkat, kejahatan pun meningkat, terutama kejahatan yang digolongkan "jalanan" seperti perampokan dan penodongan. Sedangkan korelasi sebaliknya, yaitu menurunnya kejahatan sehubungan dengan naiknya jumlah lapangan pekerjaan, belum lama ini telah terbukti secara mantap di kota-kota Amerika Serikat, khususnya New York, mulai pada tahun-tahun terakhir masa pemerintahan Bill Clinton yang pertama. Kasus ini telah dimanfaatkan perencana kota di mana-mana, agar mengarahkan pembangunan perkotaan pada penciptaan lapangan pekerjaan, dan memusatkan perhatian pada kawasan-kawasan kumuh di dalam kota (inner cities). ${ }^{42}$

Angka kriminalitas di kota sangat tinggi, hal ini dapat dilihat dari berbagai tayangan di televisi dan juga berbagai berita yang dimuat dalam berbagai media massa. Kejahatan di kota seakan terus bertambah seiring dengan upaya pemerintah untuk menangkap berbagai pelaku kejahatan ini. Jika dicermati, maka dapat dipahami bahwa kejahatan semakin hari semakin meningkat karena masyarakat tidak mengalami kesejahteraan dan juga karena lapangan pekerjaan tidak cukup seiring dengan pertambahan penduduk sehingga angka pengangguran sangat tinggi. Para pelaku kejahatan ini juga semakin profesional terbukti bahwa dalam melaksanakan aksi kejahatannya mereka memiliki modus operandi yang terbilang rapi dan juga mempergunakan metode dan teknologi canggih. Akhirnya, seperti halnya dengan prostitusi, maka kejahatan pun telah dijadikan sebagai mata pencaharian.

\footnotetext{
${ }^{40}$ Ibid., 213.

41 Kartono Kartini, Patologi Sosial (Jakarta: PT Raja Grafindo Persada, 2001), 125.

${ }^{42}$ Chris Verdiansyah (Editor), Politik Kota Dan Hak Warga Kota (Jakarta: Kompas, 2006), 90.
} 


\section{Menjangkau Masyarakat Perkotaan}

Allah yang merencanakan kota. Kita dapat mengetahui dengan pasti bahwa Ia menghendaki kita berkumpul dalam komunitas kota dengan maksud untuk kebersamaan. Tuhan membuat ini jelas dalam bagian pembukaan dari Alkitab ketika Dia memerintahkan Adam dan Hawa untuk beranak cucu dan memenuhi bumi (Kej. 1:27-28). ${ }^{43}$ Kota adalah gagasan Allah, dan Dia bermaksud kota menjadi berkat dan bukan kutuk, bahwa kota memiliki kepribadian yang nyata dan karakter rohaninya sendiri, bahwa karakter yang jahat dari kota berkembang disebabkan individu-individu dan pilihan-pilihan dari korporat manusia yang membuatnya dan bahwa orang percaya memiliki tanggung jawab untuk kesejahteraan kota mereka. ${ }^{44}$ Kompleksitas kehidupan masyarakat kota merupakan tantangan sekaligus peluang bagi gereja untuk menjangkau jiwa-jiwa bagi Kristus. Ruck berpendapat bahwa: "Gereja ada untuk menyebarkan kemuliaan Allah serta kehendak-Nya di dalam masyarakat. Tugas komunitas yang percaya tetap sepanjang abad, yaitu untuk menjadi berkat bagi semua kaum di muka bumi (Kej. 12:3; Gal. 3:29). Arti dari menjadi berkat itu tersimpul dalam konsep syalom. ${ }^{45}$

Perkembangan kota serta segala kemudahan yang ada di dalamnya turut mempengaruhi kehidupan masyarakat kota. Kota yang semakin maju membuat penduduknya cenderung untuk semakin mengejar hal-hal berhubungan dengan pemenuhan kebutuhan jasmani dibandingkan dengan hal-hal rohani. Dampaknya ialah nilai-nilai hidup spiritualitas masyarakat kota semakin merosot sehingga dapat dikatakan bahwa banyak orang di kota yang terhilang secara rohani. Budaya hidup masyarakat kota serta masalah-masalah yang ada di dalamnya seharusnya membuat gereja secara serius menyiapkan langkah-langkah strategis untuk menjangkau penduduk kota.

\section{Memperlengkapi Jemaat Untuk Bersaksi}

Untuk menjangkau masyarakat kota yang majemuk maka para pemimpin gereja harus melatih setiap anggota jemaat untuk melaksanakan amanat agung Tuhan Yesus. Pelatihan ini bertujuan agar setiap anggota jemaat siap menjadi saksi Kristus di lingkungan dimana dirinya berada. Sehubungan dengan pelatihan tersebut maka para pemimpin gereja harus mempersiapkan berbagai materi praktis yang didesain sebagai sebuah kurikulum untuk digunakan dalam memperlengkapi setiap anggota jemaat sehingga pada akhirnya mereka terlatih guna melaksanakan amanat agung Tuhan Yesus. Pentingnya pelatihan ini ialah disamping memberikan rasa percaya diri kepada para anggota jemaat untuk melaksanakan amanat agung tetapi juga bertujuan untuk meminimalisir berbagai kesalahan yang mungkin timbul dalam melaksanakan tanggung jawab tersebut. Peters berpendapat bahwa: "Mempertahankan atau membiarkan anggota gereja tetap pasif bukan hanya merupakan kegagalan dalam pelayanan, melainkan dosa terhadap panggilan dan rencana khusus Allah

\footnotetext{
${ }^{43}$ McClung Floyd, Pelayanan Metropolitan (Jakarta: YWAM Publishing, 1999), 53.

${ }^{44}$ Ibid., 62.

${ }^{45}$ John Ruck and Anne Ruck, Jemaat Misioner (Jakarta: YKBK, 2015), 188.
} 
bagi gereja. Itu mengabaikan maksud Allah dan menggagalkan karunia Allah kepada orang percaya secara individu. ${ }^{46}$ Keterlibatan (partisipasi) adalah hal yang paling penting. Ketidakaktifan melahirkan ketidaktertarikan, acuh, dan akhirnya masa bodoh. ${ }^{47}$

Jemaat yang telah diperlengkapi untuk melaksanakan amanat agung akan menghasilkan sebuah gerakan misi yang berdampak luas bagi penjangkauan jiwa-jiwa. Masyarakat kota yang majemuk akan dapat mendengar berita injil apabila setiap anggota jemaat bersama bergerak menjadi saksi Kristus. Peter Wongso menggunakan istilah "tenagatenaga jembatan" dalam hubungannya dengan menggerakkan jemaat untuk terlibat dalam amanat agung Tuhan Yesus. Peter Wongso berpendapat bahwa: "Bila seluruh anggota jemaat digerakkan untuk membagikan traktat, mengadakan penginjilan pribadi, titik penginjilan akan menjadi banyak dan bidang penginjilan menjadi luas. Tenaga-tenaga ini perlu diberikan latihan dasar dahulu, kemudian baru menyuruh mereka memakai prinsip-prinsip yang telah diajarkan."48 Penduduk kota akan dapat dijangkau dengan injil apabila setiap jemaat menyadari dan melaksanakan tanggung jawabnya sebagai saksi Kristus yang ditempatkan Allah di tengah-tengah kota.

\section{Menyediakan Pusat Konseling}

Kota memiliki berbagai macam permasalahan sehingga turut mempengaruhi nilainilai, pola pikir serta perilaku masyarakatnya. Kompleksitas permasalahan kota juga cenderung membuat individu-individu di kota menjadi rentan terhadap gangguan mentalpsikologis sehingga dapat merusak hubungan-hubungan antar pribadi, keluarga dan juga dalam hidup bermasyarakat. Floyd menegaskan bahwa: "Yesus tidak sekedar mendengarkan kata-kata melainkan juga hati. Dia sungguh-sungguh mendengarkan. Dia berhenti pada siang hari, dekat sumur untuk bercakap-cakap dengan wanita Samaria. Dia merangkul anak-anak di pelukan-Nya dan berbicara bersama mereka, mendengar dengan sungguh sebagaimana mereka bercakap-cakap. Dia keluar dari jalan-Nya untuk bersama-sama dengan orang-orang. Jenis mendengarkan seperti ini membutuhkan waktu. Ini berarti menyela rencana-rencana kita. Itu juga artinya merasakan apa yang dirasakan oleh orang lain, menangis dengan mereka yang menangis, bukanlah sekadarnya saja sehingga kita memenangkan mereka demi alasan kita melainkan karena kita sungguh-sungguh memperhatikan." 49

Gereja harus menyikapi kompleksitas permasalahan kota sebagai peluang untuk menjangkau setiap orang dalam masyarakat. Untuk itu gereja perlu menyediakan suatu bentuk layanan konseling yang menjawab kebutuhan masayarakat kota. Pelayanan konseling ini merupakan bentuk kepedulian gereja untuk mendengarkan dan memperhatikan dari dekat keadaan individu-individu yang memerlukan pertolongan serta memberikan solusi yang tepat

\footnotetext{
${ }^{46}$ George W. Peters, Teologi Pertumbuhan Gereja (Malang: Gandum Mas, 2002), 270.

${ }^{47}$ Ibid., 271.

${ }^{48}$ Peter Wongso, Tugas Gereja Dan Misi Masa Kini (Malang: Seminari Alkitab Asia Tenggara, 1996),

${ }^{49}$ McClung Floyd, Pelayanan Metropolitan (Jakarta: YWAM Publishing, 1999), 91.
}

93. 
menyangkut berbagai aspek pergumulan dalam kehidupan. Kepedulian gereja terhadap orangorang di kota sejalan dengan apa yang dilakukan oleh Yesus yang datang kedalam dunia untuk mencari dan menyelamatkan yang terhilang, Lukas 19:10.

Pentingnya pelayanan konseling mengharuskan gereja mempersiapkan para konselor untuk melayani warga kota yang memerlukan pertolongan. Para konselor ini harus diseleksi dan diperlengkapi dengan berbagai pengetahuan umum dan pengajaran alkitab sehingga dapat menjalankan tugas sebagai seorang konselor dengan baik. Patut diperhatikan bahwa pelayanan konseling ini pada akhirnya berujung pada upaya untuk memperkenalkan Kristus Yesus kepada orang yang dilayani sehingga pada waktunya mereka dapat menerima Dia sebagai Juruselamat pribadi.

\section{Aksi Sosial}

Halim menegaskan bahwa: "Gereja dibangun bukan hanya untuk mengurus urusan organisasi, administrasi, dan pengerja dan jemaatnya, tetapi juga memiliki orientasi kemasyarakatan. Gereja juga perlu terlibat dengan kegiatan-kegiatan kemasyarakatan, dan bersama-sama masyarakat untuk membangun masyarakat itu sendiri. Hubungan sosial gereja dengan masyarakat mencerminkan aspek-aspek sosial dalam kekristenan." Dalam konteks lingkungan sosial, maka dapat dikatakan bahwa segala sesuatu dari masyarakat, untuk masyarakat, bagi masyarakat, demi kemajuan dalam masyarakat." ${ }^{, 50}$ Gereja harus terlibat aktif dalam berbagai kegiatan di tengah masyarakat untuk memberi pengaruh nyata. Keterlibatan gereja ini merupakan bagian untuk menjalankan peran sebagai garam dan terang di tengahtengah dunia yang rusak dan gelap. Berbagai kegiatan sosial yang merupakan wujud dari pelayanan kasih dapat menjadi sarana atau jalan masuk bagi gereja untuk membawa kasih Allah ke dalam kehidupan masyarakat kota. Ruck berpendapat bahwa: "Pelayanan kasih dalam bentuk menolong orang miskin, melakukan berbagai kebaikan yang mendatangkan damai sejahtera bagi masyarakat, merupakan karakter komunitas misioner. ${ }^{51}$ Komunitas misioner yang membawa kabar baik kepada orang bukan Kristen melalui pelayanan kasih, seharusnya murni didorong oleh kasih Kristus dan bukan dengan motivasi lain. Mereka senang berbagi dari kekurangan mereka dan tidak mengharapkan balasan apa pun karena itu merupakan ucapan syukur kepada Tuhan yang telah menyelamatkan mereka. ${ }^{52}$ Prinsip dari aksi sosial sebagai wujud dari pelayanan kasih ialah untuk menyatakan kasih Kristus kepada masyarakat sehingga mereka dapat melihat Kristus hidup dalam diri orang percaya.

Gereja dapat menjadi penggerak terciptanya kebersihan lingkungan dengan memobilisasi umat untuk membersihkan lingkungan di mana gereja ada. Gereja juga dapat membangun hubungan sosial yang luas dengan melakukan pelayanan kesehatan kepada masyarakat atau mengadakan aksi donor darah yang bekerja sama dengan pemerintah untuk membantu ketersediaan darah bagi masyarakat yang memerlukan. Dalam kehidupan masya-

\footnotetext{
${ }^{50}$ Makmur Halim, Gereja Di Tengah-Tengah Perubahan Dunia (Malang: Gandum Mas, 2000), 238.

51 John Ruck and Anne Ruck, Jemaat Misioner (Jakarta: YKBK, 2015), 448.

${ }^{52}$ Ruck and Ruck, Jemaat Misioner.
} 
rakat kota seringkali ada banyak bencana yang terjadi seperti kebakaran, banjir, gempa bumi dan lainnya. Gereja dapat mengambil inisiatif untuk meringankan beban orang-orang yang tertimpa bencana dengan memberikan bantuan sosial sesuai dengan kebutuhan para korban. Gereja harus peka terhadap berbagai peristiwa yang terjadi dalam masyarakat kota sehingga dapat digunakan sebagai jalan masuk untuk menyatakan kasih Allah bagi dunia. Karena itu penting bagi gereja untuk memiliki program khusus demi menjangkau masyarakat sekitar sehingga misi Allah dapat dilakukan secara berkesinambungan.

\section{Mendirikan Lembaga Pendidikan}

Gereja adalah sahabat orang-orang miskin! Tuhan Yesus Kristus yang adalah Kepala Gereja juga pernah berkotbah tentang kebahagiaan orang miskin. Tongkat estafet membawa shalom lewat pendidikan telah diberikan kepada gereja. ${ }^{53}$ Artinya, gereja mesti segera merealisasikan dan membuktikan peran sertanya dalam pembangunan pendidikan guna mencapai tujuan Pendidikan Nasional guna menjadikan bangsa yang adil, makmur dan hidup sentosa. ${ }^{54}$ Ladang pelayanan misi di kota begitu luas karena itu mendirikan lembaga-lembaga pendidikan adalah cara penting untuk menjangkau masyarakat kota yang heterogen. Beberapa organisasi gereja di perkotaan telah melihat peluang pelayanan misi tersebut sehingga gereja membentuk yayasan yang menyelenggarakan pendidikan, baik itu pendidikan umum mulai dari tingkat PAUD (Pendidikan Anak Usia Dini) hingga PT (Perguruan Tinggi) maupun pendidikan yang sifatnya kursus. Kursus ini bertujuan untuk memberikan berbagai macam pelatihan ketrampilan.

Gereja harus mendorong lembaga-lembaga pendidikan (khususnya pendidikan Kristen) yang dikelolanya agar dapat memberikan space untuk rakyat miskin. Supaya mereka dapat menikmati dan mengenyam pendidikan. Memberikan porsi yang sama dengan golongan-golongan yang lainnya. Meminimalisasi jurang pemisah pembedaan antara pendidikan bagi orang miskin dan pendidikan untuk orang kaya. ${ }^{55}$ Pelayanan misi yang dilakukan melalui lembaga pendidikan ini memiliki dampak yang signifikan karena akan menyentuh berbagai kelompok sosial seperti anak-anak, remaja, dan kaum muda, bahkan orang tua. Gereja harus menyeleksi para pendidik (guru) atau pelatih yang akan direkrut dan akan ditempatkan di sekolah-sekolah tersebut serta menjelaskan pelayanan misi yang hendak dicapai oleh gereja melalui lembaga pendidikan tersebut.

\section{Membuat Grup Olahraga}

Olahraga dapat menjadi sarana yang memudahkan orang percaya untuk masuk ke dalam hubungan yang lebih dekat dengan masyarakat di sekitarnya. Melalui sarana olahraga setiap jemaat dapat berinteraksi dan membangun persahabatan dengan masyarakat kota yang juga memiliki minat atau hoby yang sama. Ruck berpendapat bahwa: "Tujuan dari kebera-

\footnotetext{
53 Japarlin Marbun, "Peranan Gereja Bagi Pendidikan Nasional," Regula Fidei 1, no. 1 (2016): 148.

${ }_{54}$ Marbun, "Peranan Gereja Bagi Pendidikan Nasional."

55 Ibid., 149.
} 
daan gereja adalah untuk menarik manusia kepada Kristus dan melayani mereka agar semakin seperti Kristus. ${ }^{56}$ Sebagai pengantara dari kasih Allah dalam Kristus, mereka harus menjadi sahabat yang mengungkapkan realita dari kasih, agape Kristen dalam setiap kata, sikap, dan tindakan. Dengan demikian tercipta peluang untuk menyampaikan inti dari kerajaaan Allah. ${ }^{57}$

Pelayanan akan semakin efektif apabila gereja mulai membentuk grup-grup olahraga (grup futsal, basket, badminton, bola voli, dan lainnya) dalam jemaat berdasarkan kelompok usia yaitu grup untuk anak-anak, remaja, kaum muda, bahkan orang dewasa, sesuai dengan kebutuhan untuk penjangkauan masyarakat. Gereja juga dapat menyiapkan anggaran khusus sehingga kegiatan ini dapat berlangsung secara rutin. Semua jemaat yang terlibat dalam kegiatan ini sebelumnya harus diperlengkapi untuk tujuan misi sehingga setiap jemaat menyadari bahwa berita injil harus disampaikan. Olahraga hanyalah metode penjangkauan namun pemberitaan injil adalah tujuan utama yang harus dilakukan oleh setiap jemaat yang terlibat dalam kegiatan ini. Berita injil tidak boleh dikurangi untuk alasan apapun.

\section{Kesimpulan}

Tuhan memanggil setiap orang percaya untuk memberitakan injil kepada seluruh manusia yang ada di berbagi tempat, baik yang ada di daerah pedesaan yang terpencil maupun kepada masyarakat yang ada di perkotaan. Salah satu hal penting yang perlu diperhatikan dalam pemberitaan injil ialah mempelajari tempat, lokasi, masyarakat dan budaya setempat sehingga pemberitaan injil dapat dilakukan dengan baik.

Masyarakat perkotaan sangat heterogen karena penduduknya berasal dari berbagai latar belakang suku, bangsa, budaya, kepercayaan dan juga berbeda-beda dalam pola pikir. Globalisasi yang ditandai dengan perkembangan ilmu pengetahuan dan kemajuan teknologi sangat mempengaruhi kehidupan masyarakat kota sehingga dinamika kehidupan di kota begitu tinggi dan budaya kehidupan di kota juga mengalami perkembangan yang pesat. Berbagai kemajuan dan perkembangan yang terjadi di kota memiliki dampak baik secara positif maupun negatif bagi kehidupan para warganya. Hal ini tentunya menjadi tantangan dan kesempatan bagi gereja untuk melayani dan menjangkau masyarakat yang ada di kota.

Berbagai cara dapat digunakan oleh gereja untuk menjangkau masyarakat di kota. Tentunya cara atau metode yang digunakan bertujuan untuk memudahkan gereja masuk ke dalam kehidupan masyarakat kota. Untuk itu gereja perlu merencanakan dan menggunakan strategi yang tepat sesuai dengan konteks masyarakat perkotaan sehingga akhirnya berita tentang pribadi Kristus Yesus dapat tersampaikan dengan baik. Beberapa strategi yang dapat digunakan antara lain, yaitu dengan melatih setiap anggota tubuh Kristus supaya terlibat aktif dalam memberitakan injil, menyediakan pusat konseling, melakukan berbagai aksi sosial, mendirikan lembaga pendidikan, serta membuat grup olahraga.

\footnotetext{
${ }^{56}$ Ruck and Ruck, Jemaat Misioner, 196.

${ }^{57}$ Ibid., 197.
} 


\section{Rujukan}

Adityawan, I Putu Risky, and A. A Gede Agung Artha Kusuma. "Peran Materialisme Memoderasi Persepti Nilai Dan Consumer Innovativeness Terhadap Keputusan Pembelian (Studi Pada Produk Iphone Di Kota Denpasar).” E-Jurnal Manajemen 7, no. 3 (2018).

Amar. "Identitas Kota, Fenomena Dan Permasalahannya.” Ruang 1, no. 1 (2009).

Barker, Chris. Cultural Studies: Teori Dan Praktik. Yogyakarta: Bentang, 2005.

Chandra, Robby I. Budaya Kota Kawula Muda Dan Media Modern. Jakarta: Binawarga, 1998.

Chaney, David. Life Style: Sebuah Pengantar Konprehensif. Bandung: Jalasutra, 2004.

Featherstone, Mike. Postmodernisme Dan Budaya Konsumen. Yogyakarta: Pustaka Belajar, 2005.

Floyd, McClung. Pelayanan Metropolitan. Jakarta: YWAM Publishing, 1999.

George W. Peters. Teologi Pertumbuhan Gereja. Malang: Gandum Mas, 2002.

Halim, Makmur. Gereja Di Tengah-Tengah Perubahan Dunia. Malang: Gandum Mas, 2000.

Hurlock, Elisabeth B. Psikologi Perkembangan: Suatu Pendekatan Sepanjang Rentang Kehidupan. Jakarta: Erlangga, 1980.

Jamaludin, Adon Nasrullah. Sosiologi Perkotaan. Bandung: Pustaka Setia, 2017.

Kartini, Kartono. Patologi Sosial. Jakarta: PT Raja Grafindo Persada, 2001.

Kraft, Charles H. Christianity In Culture: A Study In Biblical Theologizing In Cross-Cultural Perspective. 25th Annv edition. Maryknoll, N.Y: Orbis Books, 2005.

Marbun, Japarlin. "Peranan Gereja Bagi Pendidikan Nasional." Regula Fidei 1, no. 1 (2016).

Nurhayati, Sukma Erni, and Suriani. "Sustainable Life Style Masyarakat Perkotaan (Studi Tentang Gaya Hidup Berkelanjutan Masyarakat Perkotaan Di Riau).” Sorot 11, no. 2 (2008).

Nurwati, Nunung. "Kemiskinan: Model Pengukuran, Permasalahan Dan Alternatif Kebijakan.” Jurnal Kependudukan Padjadjaran 10, no. 1 (2008).

Pujiwiyana. "Perubahan Perilaku Masyarakat Ditinjau Dari Sudut Budaya." Tradisi 1, no. 1 (2010).

Purwantini. "Urbanisme, Urbanisasi, Dan Masyarakat Urban Di Jakarta Dalam Novel Senja Di Jakarta." Atavisme 19, no. 2 (2016).

Rasyid, St. Fatimah Tola, and Ruliati. "Praktek Prostitusi Terhadap Penyalahgunaan Izin SPA.” Equilibrium IV, no. 1 (2016).

Rofhani. "Ekspresi Dan Representasi Budaya Perempuan Muslin Kelas Menengah Di Surabaya." Islamica 11, no. 2 (2017).

Ruck, John, and Anne Ruck. Jemaat Misioner. Jakarta: YKBK, 2015.

Sabarisman, Muslim. "Gaya Hidup Hedonisme Dan Fenomena Trafficking Anak: Studi Kasus Di Kota Surabaya." Sosiokonsepsia 16, no. 02 (2011).

Soekanto, Soerjono. Sosiologi Suatu Pengantar. Jakarta: PT Raja Grafindo Persada, 2002. 
Soemardjan, Selo, and Soelaeman Soemardi. Setangkai Bunga Sosiologí. Jakarta: Jajasan Badan Penerbit Fakultas Ekonomi Universitas Indonesia, 1964.

Sumardjito. "Permasalahan Perkotaan Dan Kecenderungan Perilaku Individualis Penduduknya." Cakrawala Pendidikan XVIII, no. 3 (1999).

Surbakti, Krista. "Prostitusi Di Bukit Lawang (Kajian Mengenai Faktor Penyebab Dan Respon Masyarakat Dalam Perspektif Dunia Pendidikan).” Stindo Profesional 20, no. 2 (2017).

Tacoy, Selvester M. Identitas Gereja: Sarang Penyembahan vs Sarang Penyamun. Jakarta: Calvary Media, 2005.

Tacoy, Selvester M. Membimbing Dengan Hati, Jakarta: Media Gracia, 2011.

Tanbunaan, Gideon I. Sebuah Bunga Rampai Pertumbuhan Gereja. Yogyakarta: Yayasan Andi, 1994.

Verdiansyah (Editor), Chris. Politik Kota Dan Hak Warga Kota. Jakarta: Kompas, 2006.

Wibawanto, Sigit. "Gaya Hidup Hedonisme Terhadap Perilaku Pembelian Di Pasar Modern." Fokus Bisnis 15, no. 01 (2016).

Wongso, Peter. Tugas Gereja Dan Misi Masa Kini. Malang: Seminari Alkitab Asia Tenggara, 1996.

Zaman, Saefu. "Pola Konsumtif Masyarakat Urban Dalam Perspektif Semiotik Dan Budaya." Paradigma 7, no. 1 (2017).

Zuhdiyaty, Noor, and David Kaluge. "Analisis Faktor-Faktor Yang Mempengaruhi Kemiskinan Di Indonesia Selama Lima Tahun Terakhir (Studi Kasus Pada 33 Provinsi)." Jibeka 11, no. 2 (2017). 